Trakya Eğitim Dergisi

Cilt 9, Sayı 1

Ocak 2019, 12-31

Geliș Tarihi: 25.06.2018

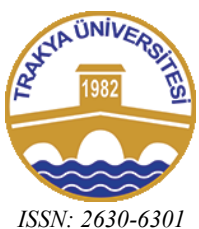

ISSN: 2630-6301
Trakya Journal of Education

Volume 9, Issue 1

January 2019, 12-31

\title{
Öğretmen Adaylarının Üniversite Yaşamına Sosyal, Kişisel ve Akademik Uyumları ${ }^{1}$
}

\author{
Social, Personal and Academic Adaptation of Pre-service Teachers to University Life
}

\author{
Hanife ESEN-AYGÜN² , Çiğdem ŞAHIN-TAŞKIN ${ }^{3}$
}

\begin{abstract}
Öz: Bu araştırmada Temel Eğitim Bölümü birinci sınıfta öğrenim gören öğretmen adaylarının üniversite yaşamına uyum süreçleri kişisel, sosyal ve akademik uyum kapsamında incelenmiştir. Bu araştırma ile öğretmen adaylarının üniversite yaşamına uyum düzeyleri çeşitli değişkenler açısından ele alınırken; uyum sürecinde rol oynayan unsurların ayrıntılı olarak incelenmesi amaçlanmıştır. $\mathrm{Bu}$ doğrultuda çalışma karma desende tasarlanmıştır. Verilerin toplanmasında Aladağ, Kağnıcı, Tuna ve Tezer (2003) tarafindan geliştirilen Üniversite Yaşamı Ölçeği ve yarı yapılandırılmış görüşme formu kullanılmıştır. Elde edilen bulgular, öğretmen adaylarının üniversite yaşamına uyum düzeylerinin çok yüksek olmadığı göstermektedir. Bununla birlikte, öğretmen adaylarının uyum düzeyleri cinsiyet, anabilim dalı ve coğrafi bölgeye göre anlamlı farklılık göstermezken, genel not ortalamasına göre notu 80-84 puan aralığında olan öğretmen adaylarının lehine anlamlı farkl11ık görülmektedir.
\end{abstract}

Anahtar sözcükler: üniversite yaşamı, akademik uyum, sosyal uyum, kişisel uyum, ögretmen adayı

Cite this article as:

Esen Aygün, H., \& Şahin Taşkın, Ç. (2019). Öğretmen adaylarının üniversite yaşamına sosyal, kişisel ve akademik uyumları. Trakya Eğitim Dergisi, 9(1): 12-31.

\section{Introduction}

\section{EXTENDED ABSTRACT}

The university years that constitute a new era in terms of social and biological aspects, such as the separation from the family, uncertainties about new friendships, occupation, and employment, are the most important issues for the individual to find their identity, adopt and mediate national and universal values, adapt to social values, cause concerns. Depending on these anxieties and problems, the distancing from the family and the near periphery and their lack of support brings with it an adaptation process. Gaining the skills of individuals to overcome new situations in which university life is caused by academic, personal and social care will facilitate their adaptation in the later years of university life. For example, it is known that the academic attainment of the students who enter with the positive attitude of the division they are studying is better. For this reason, it is thought that it is important for the teachers to determine the elements that lead to the inconsistency in university life by educating the qualified teachers of the future.

When literature is examined, there are many studies about the pre-service teachers' adaptation process to the university life, especially the pre-service teachers who are studying in the first grade. It is understood that these studies are mostly generalizations aimed at determining the level of adjustment of university students. When these studies are evaluated in terms of their results, it is noteworthy that

\footnotetext{
${ }^{1}$ Bu çalışmanın bir bölümü I. Uluslararası Temel Eğitim Kongresi’nde sözlü bildiri olarak sunulmuştur.

${ }^{2}$ Dr. Öğr. Üyesi, Çanakkale Onsekiz Mart Üniversitesi, Eğitim Bilimleri Bölümü, eposta: hanifeesen@comu.edu.tr

${ }^{3}$ Prof. Dr., Çanakkale Onsekiz Mart Üniversitesi, Temel Eğitim Bölümü, eposta: csahin@comu.edu.tr
} 
pre-service teachers are experiencing problems in terms of personal, social and academic adaptation in the first years of their education. In this research, the adaptation process of the pre-service teachers who are studying in Primary Education Department has been examined. This study is devoted to the study of the factors that play a role in the adaptation, focusing on the social, personal and academic adaptation levels of the pre-service teachers who are the first to meet the children who start the school.

The task of teachers is to train academically competent students, but one of the most important functions of the school is to prepare children for life. It is thought that it is possible to educate individuals who are adapted with the society if teachers first have their own adaptations. For this reason, it is considered that the first step of formal education, which is the first to meet the child who leaves the home and the mother, plays an important role in ensuring the integration of pre-school and primary school teachers. Accordingly, it is considered that teachers firstly identify the elements that play a role in their adaptation and that their efforts to achieve adaptation are important. In this study, it was aimed to examine in detail the elements that play a role in the adaptation process while determining the level of academic social and personal adaptation of the pre-service teachers about university life.

\section{Method}

This research, which examines the personal, social and academic aspects of pre-service teachers' adaptation to university life, is designed in a mixed method. The participants of the quantitative part of the study was selected from first grade pre-service teachers by simple random sampling method. In this direction, 199 pre-service teachers who were educated in Primary Education Department were randomly selected. In the qualitative part of the study, the participants were determined by criterion sampling method among the first grade students. In this respect, it has been determined that the pre-service teachers who participate in this research should be educated in the first grade. As a result, 24 pre-service teachers from the Primary Education Department participated in the interviews. University Life Scale and semi-structured interview form were used to collect research data. Qualitative and quantitative data of the study were collected during the fall semester of 2017-2018 academic year.

In the analysis of quantitative data, the suitability of the normal distribution of the data set has been examined first. It has been decided to use parametric tests with the understanding that the data show normal distribution. Accordingly, $t$ test was used to examine data according to gender and discipline, one-way analysis of variance (ANOVA) tests were applied to examine the results according to geographical region and general grade average. In addition, frequencies and percentages of the data were calculated by taking into account the responses of the pre-service teachers to each subscale during the measurement. In the analysis of qualitative data, descriptive analysis technique was used. Thus, qualitative data were examined under the categories of academic adjustment, social adjustment and personal adjustment.

\section{Result and Discussion}

When the findings are examined, it is understood that the adaptation of the pre-service teacher to university life is moderate. It is seen that there is a meaningful difference in favor of female preservice teacher within the scope of academic adaptation while there is no significant difference according to the university environment, emotional adaptation, relation other gender, personal adaptation and social adaptation. This result can be explained by the attitudes of female pre-service teachers regarding the profession who have a more favorable opinion than male pre-service teachers in the context of academic adaptation.

There is no significant difference between the level of adaptation of the pre-service teachers who studying in Primary Teacher Education and Pre-school Teacher Education. It is considered that the attitudes and expectations of the pre-service teachers regarding the teaching profession are similar, so that the level of adaptation of the groups to the university life is similar to each other.

There is a statistically significant difference between the prospective teacher candidates when considering the academic achievement of their university level of adaptation. It is understood that the adaptation levels of pre-service teacher with a general grade average of 85-89 are more positive. Literature shows that the reasons for entering the university effect not only adaptation to university life but also on academic achievement for pre-service teachers. Based on this, it is believed that the 
adaptation of the pre-service teachers to the university life is more positive because they are not academically challenged.

Another variable addressed in this study is the geographical regions where the pre-service teachers came from. There is no significant difference between the level of adaptation of the pre-service teachers to the university life and the geographical region they came from. This finding is similar to the results of previous studies. When the characteristics of participants are examined, it is seen that preservice teachers from all geographical regions have participated in the study. Although there is no significant difference in the analysis of data obtained from the scale, Findings from the interviews show that pre-service teachers from İzmir are very similar to the cities where they have studied and therefore they have stated that they have not experienced the problem of adaptation. It is also seen that preservice teachers from the more distant geographical regions such as Diyarbakır and Ağr1 expressed difficulty in establishing a bond. Although there is no statistically significant difference in the findings obtained from the quantitative data, it is understood that the students who come from the regions close to the city where the study is conducted like İzmir and İstanbul are more positive in terms of the qualitative findings.

\section{GIRIŞ}

Uyum kavramı incelendiğinde organizmanın yaşamsal faaliyetlerini sürdürdüğü ortam ile bütünleşmesini ifade ettiği görülmektedir. Bununla beraber, bazı araştırmacılar tarafından uyum kavramının canlının geçirmiş olduğu biyolojik kökenli değişim (Erdoğan, Şanlı, \& Şimşek-Bekir, 2010) bazıları tarafından ise psikolojik temelli ortaya çıkan yeni durumların üstesinden gelebilme becerisi olarak tanımlandığı görülmektedir (Bilal, 1984; Alpan, 1992; Kızıltan, 1984). Bu tanımlardan farklı olarak bazı araştırmacılar da uyumu bireyin kendi benliği ile çevresel etkenler arasında dengeleme durumu olarak açıklamaktadır (Köknel, 1993). Bu bilgilerden hareketle, uyumun hem bireyin kendisi ile hem de çevresi ile ilgili bir durum olduğu anlaşılmaktadır. Bireyler, yeni bir okula başlama, yeni bir çevreye taşınma, evlenme, şehir değiştirme ve işe girme gibi çeşitli sebeplerle yaşamlarının bazı dönemlerinde uyum sürecinden geçmektedir (Çakar \& Arbak, 2004; Çalık, 2006; Şendil \& Korkut, 2008; Tüzer \& Tuncel, 2010). Araştırmacılar uyumu, kişisel, sosyal ve akademik olmak üzere üç farklı boyutta tanımlamaktadır. Yalnızlıkla baş etme becerisi ve yeni yaşama ilişkin motivasyonunu ifade eden (Gerdes \& Mallinckrodt, 1994) kişisel uyum, öğretmen adayının duygusal uyumu ve karşı cinsle olan ilişkilerini içermektedir (Karahan, Sardoğan, Özkamalı \& Dicle, 2005; Mercan \& Yıldız, 2011). Üniversite yaşamına uyum sosyal uyum altında yorumlanmıştır. Sosyal uyum adayın, üniversitenin bulunduğu şehre alışma ve arkadaşlık ilişkileri kurma becerisini ifade etmektedir (Bülbül \& AcarGüvendir, 2014; Mercan \& Yıldız, 2011). Akademik uyum ise üniversitenin getirdiği yeni akademik becerilerle baş etme ve öğretim elemanları ile olan iletişimi kapsamaktadır (Bülbül \& Acar-Güvendir, 2014; Karahan, Sardoğan, Özkamalı \& Dicle, 2005).

Yukarıdaki açıklamalar doğrultusunda, üniversite yaşamının pek çok öğrenci için yeni bir şehir, yeni bir ortam ve yeni bir okul gibi unsurların etkisiyle uyum sürecini gerektiren bir dönem olduğu görülmektedir (Bülbül \& Acar-Güvendir, 2014; Erdoğan, Şanl1, \& Şimşek-Bekir, 2010). Sosyal ve biyolojik açıdan yeni bir dönemi oluşturan üniversite yılları aileden uzaklaşma, yeni arkadaşlıklar, meslek sahibi olma ve istihdama ilişkin belirsizlikler gibi pek çok sorunla birlikte; bireyin kendi kimliğini bulma, ulusal ve evrensel değerleri benimseme ve uzlaştırma, toplum değerlerine uyum sağlama, sosyal olgunluğa erişme gibi konularda kaygılara neden olmaktadır (Özdel, Bostancı, Özdel \& Oğuzhanoğlu, 2002; Özgüven, 1992; Özkan \& Yılmaz, 2010). Bu kayg1 ve sorunlara bağlı olarak, aileden ve yakın çevreden uzak kalma ve onların desteğinden yoksun olma durumu bir uyum sürecini de beraberinde getirmektedir (Karahan, Sardoğan, Özkamalı \& Dicle, 2005; Özkan \& Yılmaz, 2010).

Bireylerin üniversite yaşantısının akademik, kişisel ve sosyal bakımdan neden olduğu yeni durumların üstesinden gelme becerisini kazanmaları üniversite yaşamlarının ileriki yıllarında onlara uyum bakımından kolaylık sağlayacaktır (Erdoğan, Şanlı \& Şimşek-Bekir, 2005). Örneğin, öğrenim gördüğü bölüme olumlu tutum ile giren öğrencilerin akademik uyumlarının daha iyi olduğu bilinmektedir (Charlton, Barrow \& Hornby-Atkinson. 2006). Bu nedenle, geleceğin nitelikli öğretmenlerini yetiştirmede öğretmen adaylarının üniversite yaşamında uyumsuzluğa yol açan unsurların belirlenmesinin, öğretmenlerin topluma uyumlu bireyler yetiştirme sorumluluğu açısından önemli olduğu düşünülmektedir. 
Alanyazın incelendiğinde öğretmen adaylarının üniversite yaşamına uyum süreci ile ilgili, özellikle birinci sınıfta öğrenim gören öğretmen adaylarını konu alan, pek çok çalışma bulunmaktadır. $\mathrm{Bu}$ çalışmaların çoğunlukla üniversite öğrencilerinin uyum düzeylerini belirlemeye yönelik genelleme amacı taşıyan çalışmalar olduğu anlaşılmaktadır (Aktaş, 1997; Bülbül \& Acar-Güvendir, 2014; Erdoğan, Şanlı \& Bekir, 2005; İkiz \& Otlu, 2015; Karahan, Sakdoğan, Özkamalı, Dicle, 2010; Mercan \& Yıldız, 2011; Özkan\& Yılmaz, 2010; Sürücü \& Bacanl1, 2010). Örneğin; Özkan ve Yılmaz (2010) üniversite öğrencilerinin üniversite yaşamına uyumunu bireysel uyum kapsamında incelemiştir. Mercan ve Yıldız (2010) ile Bülbül ve Acar-Güvendir (2014) ise öğretmen adaylarının birinci sınıfta karşı karşıya kaldıkları uyum sorunlarını hem akademik hem de sosyal açıdan ele almışlardır. Bunlara ek olarak Öztemel (2010) teknik eğitim fakültesi öğrencilerinin, Sürücü ve Bacanlı (2010) eğitim fakültesi öğrencilerinin üniversite yaşamına uyumunu çeşitli değişkenler açısından incelemiştir. Birinci sınıfta öğrenim gören öğretmen adayları ile yapılan bu çalışmalardan farklı olarak Aktaş (1997) üniversite öğrencilerinin uyum sorunlarını boylamsal olarak inceleyip birinci ve dördüncü sınıf arasındaki uyuma yönelik ilişkiyi kişisel, sosyal ve genel uyum açısından değerlendirirken; Erdoğan, Şanlı ve ŞimşekBekir ise (2005) birinci ve ikinci sınıfta öğrenim gören öğretmen adaylarının üniversite yaşamına uyumunu bireysel uyum kapsamında incelemiştir. Bununla birlikte, bazı çalışmalarda üniversite yaşamına uyum ile psikolojik dayanıklılık, yaşam doyumu ve tercih sebepleri gibi değişkenler arasındaki ilişki araştııılmıştır. Örneğin; Bulut ve Bulut-Serin (2016) öğretmen adaylarının üniversite yaşamına uyum düzeyleri ile yaşam doyumu arasındaki ilişkiyi, Sertel, Yıldırım ve Özmen-Akyol (2017) üniversite öğrencilerinin tercih sebepleri ve uyum düzeyleri arasındaki ilişkiyi, Kaba ve Keklik (2016) ise üniversite yaşamına uyumu, psikolojik dayanıklılık ve psikolojik belirti düzeyleri arasındaki ilişkiyi incelemiştir.

Yukarıdaki çalışmalar incelendiğinde bu çalışmaların tamamının nicel olduğu anlaşılmaktadır. Bununla beraber, bu çalışmalardan farklı olarak; Sevinç ve Gizir (2014) üniversiteye uyum sürecinde rol oynayan unsurları, İkiz ve Mete-Otlu (2015) ise gençlerin üniversite yaşamına uyum sürecinde yaşadıkları sorunlar hakkındaki görüşlerini nitel araştırma yöntemlerini kullanarak ayrıntılı olarak incelemiştir. Ayrıntılı açıklanacak olursa, Sevinç ve Gizir (2014) yaptıkları araştırmada üniversite öğrencilerinin akademik uyumlarının fakülte ile ilişkiler ve öğretimin kalitesinden, sosyal uyumun arkadaşl1k ilişkileri ve sosyalleşmeye ayrılan zamanın yönetiminden, bireysel uyumun ise utangaçlık, başarısız olma korkusu, yalnızlık gibi faktörlerden olumsuz etkilendiğini vurgulamışlardır. İkiz ve Mete-Otlu (2015) ise üniversite öğrencilerinin önemli bir bölümünün yalnızlık hissine kapıldığı, grup içinde uyuşmazlıklar yaşadıkları, uyku ve yeme bozuklukları şikâyetlerinin olduğunu ortaya koymuştur. Bu yaşanan sorunların kişisel, sosyal ve genel uyumu içerdiği anlaşılmaktadır. Bütün bu çalışmalar sonuçları bakımından değerlendirildiğinde, öğretmen adaylarının öğrenim yaşantılarının ilk yıllarında kişisel, sosyal ve akademik açıdan uyum sorunu yaşadıklarına dikkati çekmektedir. Üniversite yaşamına uyumu konu alan araştırmalar incelendiğinde, Temel Eğitim Bölümü’nde öğrenim gören öğretmen adaylarının uyum süreçlerini inceleyen çalışmaların oldukça sınırlı olduğu (Bülbül \& Acar-Güvendir, 2014; Mercan \& Yıldız, 2011) dikkati çekmektedir. Bu doğrultuda, Temel Eğitim bölümünde öğrenim gören Sınıf ve Okul Öncesi Öğretmen adaylarının uyum süreçlerinin ayrıntılı olarak ele alınmadığ 1 düşünülmektedir. Bu bilgilerden hareketle, bu araştırmada Temel Eğitim bölümünde öğrenim görmekte olan öğretmen adaylarının üniversite yaşamına uyumları incelenmiştir. $\mathrm{Bu}$ çalışma, okula başlayan çocuğu ilk karşılayacak kişiler olan Temel Eğitim Bölümü öğretmen adaylarının sosyal, kişisel ve akademik uyum düzeylerine bir bütün olarak odaklanan ve uyumda rol oynayan etkenlerin detaylı olarak incelenmesi bakımından alanyazındaki çalışmalardan ayrılmaktadır. Bir diğer ifade ile bu çalışmanın hem öğretmen adaylarının uyum düzeylerini ele alması hem de uyum sürecinde rol oynayan faktörleri ayrıntılı olarak betimlemesi çalışmanın özgün yönünü oluşturmaktadır. Ayrıca, öğretmen adaylarının üniversite yaşamını uyumunu inceleyen çalışmaların büyük bir bölümünde nicel araştırma yöntemlerinin kullanıldığı; sınırlı sayıdaki araştırmalarda ise nitel araştırma yöntemlerinin kullanıldı̆̆ 1 (Sevinç \& Gizir, 2014; İkiz \& Mete-Otlu, 2015) görülmektedir. Bu araştırmada ise daha önceki çalışmalardan farklı olarak, öğretmen adaylarının üniversite yaşamına uyumları nicel ve nitel araştırma yöntemleri bir arada kullanılarak ayrıntılı olarak incelenmiştir.

Öğretmenlik mesleği genel yeterlikleri göz önünde bulundurulduğunda her ne kadar okulların ve öğretmenlerin görevi akademik olarak yetkin öğrenciler yetiştirmek olsa da okulun en önemli işlevlerinden biri çocukları hayata hazırlamaktır (Milli Eğitim Bakanlığı [MEB], 2017). Bu doğrultuda toplumla uyumlu bireyler yetiştirmenin öncelikle öğretmenlerin kendi uyumlarını sağlamış olmaları ile 
mümkün olacağı düşünülmektedir. Bu nedenle, evden ve anneden ayrılan çocuğu ilk karşılayacak kişiler olan Okul Öncesi ve Sınıf öğretmenlerinin uyumunun sağlanması önemlidir. Buna bağlı olarak, öncelikle öğretmenlerin kendi uyumlarında rol oynayan unsurları belirlemeleri ve uyum sağlamaya yönelik bilinçli çaba göstermeleri önem kazanmaktadır. Bu araştırmadan elde edilen bulguların Temel eğitim bölümünde öğrenim gören öğretmen adaylarının üniversiteye uyumlarını sağlamaya yönelik bilinçlenmelerine katkıda bulunacağı düşünülmektedir. Bu doğrultuda araştırmanın amaçları aşağıdaki gibidir:

$\mathrm{Bu}$ araştırmada Temel Eğitim Bölümü birinci sınıfta öğrenim gören öğretmen adaylarının üniversite yaşamına uyum süreçleri kişisel, sosyal ve akademik uyum kapsamında incelenmiştir. Bu çalışma ile öğretmen adaylarının üniversite yaşamına ilişkin akademik sosyal ve kişisel uyum düzeyleri belirlenirken, uyum sürecinde rol oynayan unsurların da detaylı olarak incelemesi amaçlanmıştır. $\mathrm{Bu}$ amaca bağlı olarak araştırma soruları aşağıdaki gibi belirlenmiştir:

1. Öğretmen adaylarının üniversite yaşamına ilişkin uyum düzeyleri nedir?

2. Öğretmen adaylarının üniversite yaşamına uyum düzeyleri cinsiyete göre anlamlı farklılık göstermekte midir?

3. Öğretmen adaylarının üniversite yaşamına uyum düzeyleri öğrenim gördükleri anabilim dalına göre anlamlı farklılık göstermekte midir?

4. Öğretmen adaylarının üniversite yaşamına uyum düzeyleri akademik başarı düzeylerine göre anlamlı farklılık göstermekte midir?

5. Öğretmen adaylarının üniversite yaşamına uyum düzeyleri adayların geldikleri bölgeye göre anlamlı farklılık göstermekte midir?

6. Öğretmen adaylarının üniversite yaşamına uyumunda rol oynayan kişisel, sosyal ve akademik unsurlar nelerdir?

\section{YÖNTEM}

\subsection{Araştırmanın Modeli}

Öğretmen adaylarının üniversite yaşamına uyumlarının kişisel, sosyal ve akademik açıdan incelendiği bu araştırma karma yöntemde tasarlanmıştır. Karma yöntem, nitel ve nicel veri toplama tekniklerinin bir arada kullanıldığı bir araştırma türüdür (Creswell \& Plano-Clark, 2007). Bu araştırma ile öğretmen adaylarının üniversite yaşamına uyum düzeyleri çeşitli değişkenler açısından ele alınırken; uyum sürecinde rol oynayan unsurların ayrıntılı olarak incelenmesi amaçlanmıştır. Bu doğrultuda, bu araştırmada yakınsayan paralel desen kullanılmıştır. Nitel ve nicel verilerin ayrı ayrı analiz edilerek, yorumlama sırasında birleştirildiği bu desende nicel ve nitel yöntemler eşit öneme sahip olmakla birlikte veriler eş zamanlı yürütülür (Creswell \& Plano-Clark, 2007).

\section{2. Çalışma Grubu}

Araştırmanın nicel bölümünün çalışma grubu birinci sınıfta öğrenim gören öğretmen adayları arasından basit seçkisiz örnekleme yöntemi kullanılarak belirlenmiştir. Basit seçkisiz örnekleme evrendeki her bir birimin eşit seçilme olasılığına sahip olduğu durumları ifade eder (Büyüköztürk vd. 2012). Bu doğrultuda, Temel Eğitim Bölümü’nde öğrenim gören 199 öğretmen adayı rastgele seçilmiştir.

Tablo 1. Demografik Özellikler

\begin{tabular}{lllll}
\hline Bölüm & Okul Öncesi Eğitimi & \multicolumn{2}{c}{ Sınıf Eğitimi } & \\
\hline Cinsiyet & Kız & Erkek & Kız & Erkek \\
\hline Mevcut & 91 & 20 & 73 & 15 \\
Toplam & 111 & & 88 & \\
\hline
\end{tabular}


Tablo 1 incelendiğinde araştırmaya 102 kadın ve 97 erkek olmak üzere toplam 199 öğretmen adayı katıldığı görülmektedir. Öğretmen adaylarının 88'i Sınıf Eğitimi, 111'i ise Okul Öncesi Eğitimi Anabilim Dalı'nda öğrenim görmektedir. Sınıf Eğitimi Anabilim Dalı'ndan 15 erkek 73 kadın öğretmen adayı, Okul Öncesi Eğitimi Anabilim Dalı'ndan 20 erkek 91 kadın öğretmen adayı çalışmaya katılmıştır.

$\mathrm{Bu}$ araştırmanın nitel bölümünde, çalışma grubu birinci sınıfta öğrenim gören öğrenciler arasından ölçüt örnekleme yöntemi ile belirlenmiştir. Ölçüt örnekleme, önceden belirlenmiş ölçütleri inceleyen durumların ele alınmasını ifade eder (Yıldırım \& Şimşek, 2008). Bu araştırma kapsamında çalışma grubu belirlenirken öğretmen adaylarının özellikle üniversite yaşamlarında kişisel, sosyal ve akademik uyumları bakımından ilk yılının önemli bir yere sahip olduğu dikkate alınmıştır (İkiz \& Otlu, 2015). Bu doğrultuda, bu araştırmaya katılan öğretmen adaylarının birinci sınıfta öğrenim görmeleri ölçüt olarak belirlenmiştir. Buna bağlı olarak, görüşmelere Temel Eğitim Bölümü’nden 24 öğretmen adayı katılmıştır.

\subsection{Veri Toplama Araçları}

\section{Üniversite Yaşamı Ölçeği}

Aladağ, Kağnıc1, Tuna ve Tezer (2003) tarafından üniversiteye yeni başlayan öğrencilerin genel olarak üniversite yaşamına uyum düzeylerini ölçmek amacıyla geliştirilen ölçek 48 maddeden oluşmaktadır. Ölçekte yer alan her maddeye verilecek yanıtlar "Bana hiç uygun değil" den "Bana tamamen uygun" a kadar uzanan seçeneklerden oluşan bir ölçek üzerinde uyumsuzluk-uyum yönünde 1 ile 7 arasında puanlanmıştır. Ölçeğin geçerliğini sağlamak amacıyla dil, içerik, kapsam ve yap1 geçerliği dikkate alınmıştır. Yapı geçerliğini sağlamak amacıyla yapılan açımlayıcı faktör analizi sonucunda altı alt boyuttan oluşan ölçek elde edilmiştir. Ölçeğin alt faktörleri üniversite ortamına uyum (12 madde), duygusal uyum ( 9 madde), kişisel uyum (7 madde), karşı cinsle ilişsiler ( 7 madde), akademik uyum (7 madde) ve sosyal uyum (6 madde) olarak adlandırılmıştır. Ölçeğin tümüne ilişkin Cronbach Alpha güvenirlik katsayı .91 olarak hesaplanırken, alt faktörlerin güvenirlik katsayısını .59 ile .77 aralığında olduğu belirlenmiştir.

\section{Görüşme Formu}

$\mathrm{Bu}$ araştırmada öğretmen adaylarının üniversite yaşamına uyum süreçleri hakkında ayrıntılı bilgi edinmek amacıyla yarı yapılandırılmış görüşmeler gerçekleştirilmiştir. Yarı yapılandırılmış görüşmeler derinlemesine bilgi edinme, soru sırasını değiştirebilme, ek sorular sorma, gözden kaçırılan noktaların görüşme sırasında eklenmesi gibi hususlarda araştırmacıya esneklik sağlayan bir görüşme türüdür (Merriam, 2013). Bu araştırmada öğretmen adaylarının üniversite yaşamına uyumunu konu alan yarı yapılandırılmış görüşme formu araştırmacılar tarafından hazırlanmıştır. Görüşme formunun geçerliğinin sağlanması amacıyla araştırmacılar tarafindan hazırlanan görüşme formu iki uzmanın görüşüne sunulmuştur. Görüşüne başvurulan uzmanlardan biri Eğitim Programları alanından Diğeri Sınıf Eğitimi alanında öğretmen adayları ile çalışmaları olan öğretim üyeleridir. Uzman görüşleri doğrultusunda görüşme soruları yeniden düzenlenmiş ve uygulanmaya hazır halde getirilmiştir.

\subsection{Verilerin Toplanması}

Araştırmanın nitel ve nicel verileri 2017-2018 akademik yılı güz yarıyılında toplanmıştır. Bu doğrultuda öğretmen adaylarına araştırmanın amacı hakkında bilgi verilmiştir. Görüşmelerden elde edilen verilerin deşifre edilmesinin ardından iki öğretmen adayına deşifre edilen verileri okuma firsatı verilerek; gerçekte ifade etmek istedikleri ile tutarlılığı bakımından incelemeleri istenmiştir. Öğretmen adaylarının ifadelerini onaylamasıyla çalışmanın iç güvenirliği artıılmıştır. Veriler, araştırmacılar tarafından toplanmıştır. Nicel veriler sınıfta yaklaşık 15-20 dakikalık sürede ders arasında toplanırken, nitel veriler ise araştırmacıların ofisinde 10-20 dakikalık sürelerde toplanmıştır.

\subsection{Verilerin Analizi}

Nicel verilerin analizinde öncelikle veri setinin normal dağılıma uygunluğu incelenmiştir. $\mathrm{Bu}$ doğrultuda veri seti 29'dan büyük olduğu için Kolmogorov-Smirnov testi yapılmıştır (Kalayc1, 2010). 
Tablo 2. Kolmogorov-Smirnov testi sonuçları

\begin{tabular}{lrrr}
\hline & Statistic & df & Sig. \\
\hline Ünivesite Yaşamına Uyum & .052 & 199 & .200 \\
\hline
\end{tabular}

Tablo 2 incelendiğinde veri setinin normal dağılıma uygun olduğu görülmektedir, $\mathrm{p}>.05$ (Kalayc1, 2010). Buna bağlı olarak, verileri cinsiyet ve anabilim dalına göre incelemek amacıyla verilere $\mathrm{t}$ testi, coğrafi bölge ve genel not ortalamasına göre incelemek amaciyla tek yönlü varyans analizi (Anova) testleri uygulanmıştır. Bunlara ek olarak, adayların ölçme aracında her bir alt ölçeğe vermiş oldukları yanıtlar dikkate alınarak verilerin frekans ve yüzdeleri hesaplanmıştır.

Nitel verilerin analizinde betimsel analiz tekniğinden yararlanılmıştır. Betimsel analiz veri setinin belirlenmiş temalara göre analiz edilmesi ve yorumlanmasını ifade eder (Yıldırım \& Şimşek, 2008). Bu kapsamda öncelikle betimsel analiz için çerçeve oluşturma, tematik çerçeveye göre verilerin işlenmesi, bulguların tanımlanması ve yorumlanması aşamaları takip edilir. Veriler araştırma sorularının ortaya koyduğu temalara göre düzenlenebileceği gibi görüşme ve gözlem süreçlerinde kullanılan sorular ya da boyutlar da dikkate alınabilir. Bu doğrultuda, bu çalışmada araştırmanın amacı doğrultusunda Şekil 1'de yer alan kavramsal çerçeve belirlenmiştir. Daha sonra, öğretmen adaylarının üniversite yaşamına uyumları bu kavramsal çerçeveye dayalı olarak ayrıntılı bir biçimde incelenmiştir.

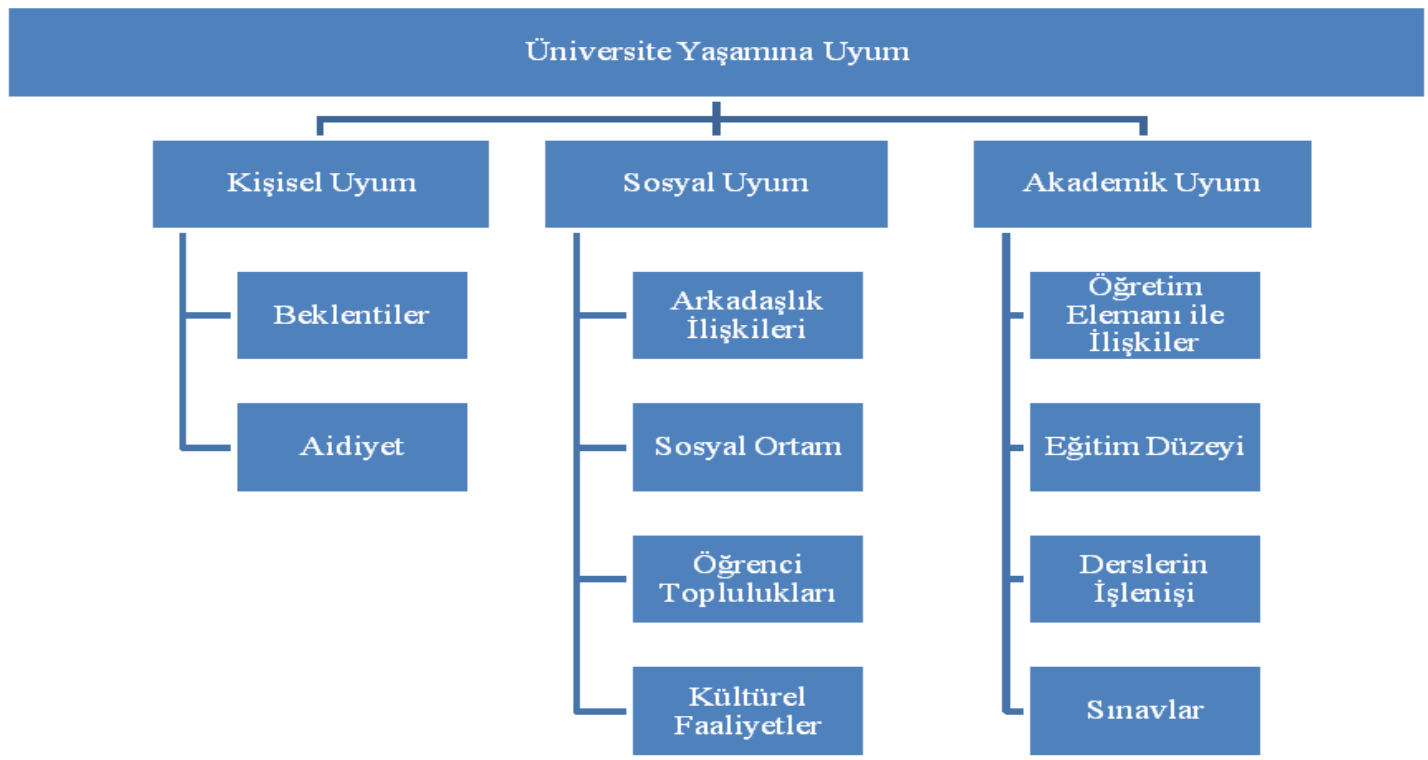

Şekil 1. Verilerin analizi.

\section{BULGULAR}

$\mathrm{Bu}$ bölümde araştırmadan elde edilen bulgular sunulmuştur. Öncelikle araştırmanın nicel bölümünü oluşturan araştırma sorularına yanıt aranmıştır. Bu doğrultuda, üniversite yaşamına uyum süreci cinsiyet, bölüm, coğrafi bölge ve genel not ortalaması değişkenlerine göre incelenmiştir. Ardından araştırmanın nitel yönünü oluşturan son araştırma sorusuna ilişkin bulgular kapsamlı olarak açıklanmıştır.

\section{1. Üniversite Yaşamı Ölçeği'ne İlişskin Bulgular} verilmiştir.

Tablo 3'te üniversite yaşamı ölçeğinden alınan puanların betimsel istatistiklerine yer 
Tablo 3. Üniversite yaşamı ölçeğine ilişkin betimsel istatistikler

\begin{tabular}{lcccccc}
\hline Faktör Adı & N & Min. & Max. & Varyans & Ss. & $\overline{\mathbf{x}}$ \\
\hline Ůniversite Ortamına Uyum & 199 & 1.50 & 6.58 & 1.08 & 1.04 & 4.74 \\
Duygusal Uyum & 199 & 1.56 & 7.00 & 1.17 & 1.08 & 4.43 \\
Kişisel Uyum & 199 & 1.86 & 7.00 & 1.10 & 1.05 & 5.41 \\
Karşı Cinsle İlişkiler & 199 & 1.00 & 7.00 & 1.21 & 1.10 & 4.97 \\
Akademik Uyum & 199 & 1.00 & 7.00 & 1.08 & 1.04 & 5.13 \\
Sosyal Uyum & 199 & 1.00 & 7.00 & 1.12 & 1.05 & 5.71 \\
Tüm Ölçek & 199 & 1.50 & 6.81 & .625 & .79 & 4.99 \\
\hline
\end{tabular}

Tablo 3 incelendiğinde öğretmen adaylarının üniversite yaşamının birinci yılında en yüksek uyumu Sosyal Uyum boyutunda gösterdikleri anlaşılmaktadır $(\bar{x}=5.71)$. Öğretmen adaylarının uyum düzeylerinin en düşük olduğu alt faktörün ise Duygusal Uyum olduğu görülmektedir $(\bar{x}=4.43)$. Adayların tüm ölçeğe ilişkin ortalama puanlarının $\bar{x}=4.99$ olduğu görülmektedir. Bu ölçme aracından alınabilecek en yüksek puanın 7.00 olduğu göz önünde bulundurulduğunda öğretmen adaylarının üniversite yaşamına uyumlarının orta düzeyde olduğu anlaşılmaktadır.

Öğretmen adaylarının üniversite yaşamına uyum düzeylerinin cinsiyet değişkenine göre analiz edilmesi sonucunda elde edilen bulgular aşağıda Tablo 4'te verilmiştir.

Tablo 4. Üniversite yaşamı ölçeğine ilişkin cinsiyete göre bağımsız $t$ testi sonuçları

\begin{tabular}{llrlrllr}
\hline Faktör & Cinsiyet & \multicolumn{1}{c}{ N } & \multicolumn{1}{c}{$\mathbf{x}$} & \multicolumn{1}{l}{ Ss. } & sd & t & \multicolumn{1}{c}{$\mathbf{p}$} \\
\hline Üniversite Ortamına Uyum & Kadın & 102 & 4.79 & 1,04 & 197 & 1.22 & .22 \\
& Erkek & 97 & 4.56 & 1.04 & & & \\
\hline Duygusal Uyum & Kadın & 102 & 4.41 & 1.10 & 197 & .75 & .45 \\
& Erkek & 97 & 4.55 & 1.00 & & & \\
\hline Kişisel Uyum & Kadın & 102 & 5.41 & 1.06 & 197 & .17 & .85 \\
& Erkek & 97 & 5.44 & .98 & & & \\
\hline Karşıı Cinsle İlişskiler & Kadın & 102 & 4.99 & 1.09 & 197 & .67 & .50 \\
& Erkek & 97 & 4.86 & 1.13 & & & \\
\hline Akademik Uyum & Kadın & 102 & 5.20 & .99 & 197 & .196 & .05 \\
& Erkek & 97 & 4.83 & 1.17 & & & \\
\hline Sosyal Uyum & Kadın & 102 & 5.70 & 1.05 & 197 & .15 & .87 \\
& Erkek & 97 & 5.73 & 1.10 & & & \\
\hline Tüm Ölçek & Kadın & 102 & 5.01 & .77 & 197 & .66 & .51 \\
& Erkek & 97 & 4.91 & .85 & & & \\
\hline
\end{tabular}

Öğretmen adaylarının üniversite yaşamına uyum düzeylerinin cinsiyet değişkenine göre farklılaşıp farklılaşmadığını gösteren Tablo 3 incelendiğinde ölçeğin tamamı için üniversite yaşamına uyumda cinsiyet değişkenine göre anlamlı farklılık bulunmadığ görülmektedir, $t(197)=.66, \mathrm{p}<.05$. Bununla birlikte, her ne kadar ölçeğe ilişkin alt faktörler incelendiğinde anlamlı farklılık görülmese de Akademik Uyum alt faktöründe kadın öğretmen adaylarının ortalama puanlarının $(\overline{\mathrm{x}}=5.20)$ erkek öğretmen adaylarından $(\bar{x}=4.83)$ oldukça yüksek olduğu anlaşılmaktadır. Bu doğrultuda, kadın öğretmen adaylarının Akademik Uyum düzeylerinin erkek öğretmen adaylarına göre daha yüksek olduğu görülmektedir. 
Öğretmen adaylarının Üniversite yaşamı ölçeğine ilişkin görüşlerinin anabilim dalına göre incelenmesi sonucunda elde edilen bulgular Tablo 5'te sunulmuştur.

Tablo 5. Üniversite yaşamı ölçeğine ilişkin anabilim dalına göre bağımsız t testi sonuçları

\begin{tabular}{llrrrrrr}
\hline Faktör & ABD & \multicolumn{1}{c}{ N } & $\overline{\mathbf{x}}$ & \multicolumn{1}{c}{ Ss. } & sd & \multicolumn{1}{c}{ t } & \multicolumn{1}{c}{$\mathbf{P}$} \\
\hline Üniversite Ortamına & Sınıf Eğitimi & 88 & 4.60 & 1.14 & 196 & 1.71 & .08 \\
& Okul Öncesi & 111 & 4.85 & .94 & & & \\
\hline Duyum & Sınıf Eğitimi & 88 & 4.27 & 1.09 & 196 & 1.89 & .06 \\
& Okul Öncesi & 111 & 4.57 & 1.06 & & & \\
\hline Kişisel Uyum & Sınıf Eğitimi & 88 & 5.24 & 1.09 & 196 & 2.02 & .44 \\
& Okul Öncesi & 111 & 5.54 & 1.00 & & & \\
\hline Karşı Cinsle İlişkiler & Sinıf Eğitimi & 88 & 5.01 & 1.09 & 196 & .34 & .73 \\
& Okul Öncesi & 111 & 4.95 & 1.10 & & & \\
\hline Akademik Uyum & Sinıf Eğitimi & 88 & 5.03 & 1.03 & 196 & 1.14 & .25 \\
& Okul Öncesi & 111 & 5.21 & 1.04 & & & \\
\hline Sosyal Uyum & Sinıf Eğitimi & 88 & 5.70 & 1.05 & 196 & .16 & .87 \\
& Okul Öncesi & 111 & 5.72 & 1.06 & & & \\
\hline Tüm Ölçek & Sınıf Eğitimi & 88 & 4.89 & .82 & 196 & 1.61 & .10 \\
& Okul Öncesi & 111 & 5.07 & .75 & & & \\
\hline
\end{tabular}

Üniversite yaşamına uyum düzeyi öğretmen adaylarının öğrenim gördüğü anabilim dalları dikkate alınarak incelendiğinde, Sınıf Eğitimi $(\overline{\mathrm{x}}=4.89)$ ve Okul Öncesi Eğitimi $(\overline{\mathrm{x}}=5.07)$ anabilim dallarında öğrenim gören adayların uyum düzeyleri arasında anlamlı farklılık olmadığı anlaşılmaktadır, $\mathrm{t}(196)=1.61, \mathrm{p}<.05$. Benzer şekilde, alt faktörler kapsamında da öğretmen adaylarının uyum düzeyleri ile öğrenim gördükleri anabilim dalı arasında anlamlı farklılık gözlenmemiştir.

Öğretmen adaylarının üniversite yaşamına uyum düzeylerinin genel not ortalamasına göre farklılık gösterip göstermediğini incelemek amacıyla varyans analizi yapılmasına karar verilmiştir. $\mathrm{Bu}$ doğrultuda öncelikle veri setinin varyans analizine uygun olup olmadığını belirlemek amaciyla Levene testi yapılmıştır. Tablo 6'da Levene testine ilişkin bulgular yer almaktadır.

Tablo 6. Varyansların homojenliği testi

\begin{tabular}{llll}
\hline Levene Statistic & df1 & df2 & Sig. \\
\hline 1.237 & 7 & 192 & .285 \\
\hline
\end{tabular}

Tablo 6'da tek yönlü Anova testinin temel varsayımı olan varyansaların homojenliği testinin sonuçları görülmektedir (Kalayc1, 2010). Ulaşılan p değeri .05'ten büyük olduğu için (.285) varyansların homojen ve varyans analizine uygun olduğu söylenilebilir (Büyüköztürk vd., 2012; Kalayc1, 2010). Tablo 7'de öğretmen adaylarının üniversite yaşamına uyum düzeylerinin genel not ortalamasına göre analiz sonuçları yer almaktadır. 
Tablo 7. Üniversite yaşamı ölçeğine ilişkin genel not ortalamasına göre varyans analizi sonuçları

\begin{tabular}{|c|c|c|c|c|c|c|}
\hline Faktör & $\begin{array}{l}\text { Varyansın } \\
\text { Kaynağı }\end{array}$ & $\begin{array}{l}\text { Kareler } \\
\text { Toplamı }\end{array}$ & sd & $\begin{array}{r}\text { Kareler } \\
\text { Ortalaması }\end{array}$ & $\mathbf{F}$ & p \\
\hline \multirow{3}{*}{$\begin{array}{l}\text { Üniversite Ortamına } \\
\text { Uyum }\end{array}$} & Gruplar aras1 & 15.36 & 7 & 3.07 & \multirow[t]{3}{*}{2.94} & \multirow[t]{3}{*}{.01} \\
\hline & Gruplar içi & 172.09 & 192 & 1.04 & & \\
\hline & Toplam & 187.46 & 199 & & & \\
\hline \multirow[t]{3}{*}{ Duygusal Uyum } & Gruplar aras1 & 10.05 & 7 & 2.01 & \multirow[t]{3}{*}{1.63} & \multirow[t]{3}{*}{.15} \\
\hline & Gruplar içi & 203.40 & 192 & 1.23 & & \\
\hline & Toplam & 213.46 & 199 & & & \\
\hline \multirow[t]{3}{*}{ Kişisel Uyum } & Gruplar aras1 & 18.84 & 7 & 3.76 & \multirow[t]{3}{*}{3.66} & \multirow[t]{3}{*}{.00} \\
\hline & Gruplar içi & 169.60 & 192 & 1.02 & & \\
\hline & Toplam & 188.45 & 199 & & & \\
\hline \multirow[t]{3}{*}{ Karşı Cinsle İliş̧kiler } & Gruplar aras1 & 22.00 & 7 & 4.40 & \multirow[t]{3}{*}{4.14} & \multirow[t]{3}{*}{.00} \\
\hline & Gruplar içi & 175.02 & 192 & 1.06 & & \\
\hline & Toplam & 197.02 & 199 & & & \\
\hline \multirow[t]{3}{*}{ Akademik Uyum } & Gruplar aras1 & 23.07 & 7 & 4.61 & \multirow[t]{3}{*}{4.65} & \multirow[t]{3}{*}{.00} \\
\hline & Gruplar içi & 163.52 & 192 & .99 & & \\
\hline & Toplam & 186.59 & 199 & & & \\
\hline \multirow[t]{3}{*}{ Sosyal Uyum } & Gruplar aras1 & 28.83 & 7 & 5.76 & \multirow[t]{3}{*}{5.72} & \multirow[t]{3}{*}{.00} \\
\hline & Gruplar içi & 166.19 & 192 & 1.00 & & \\
\hline & Toplam & 195.03 & 199 & & & \\
\hline \multirow[t]{3}{*}{ Tüm Ölçek } & Gruplar aras1 & 16.00 & 7 & 3.20 & \multirow[t]{3}{*}{5.80} & \multirow[t]{3}{*}{.00} \\
\hline & Gruplar içi & 90.99 & 192 & .55 & & \\
\hline & Toplam & 107.00 & 199 & & & \\
\hline
\end{tabular}

Öğretmen adaylarının üniversite yaşamına uyum düzeylerinin genel not ortalaması değişkenine göre incelendiği varyans analizi sonuçları dikkate alındığında, öğretmen adaylarının ölçeğin tamamında üniversite yaşamına uyum düzeyleri ile genel not ortalaması arasında anlamlı farklılık olduğu anlaşılmaktadır, $F(7,192)=5.80, p<.05$. Üniversite yaşamına uyumun tüm faktörleri dikkate alındığında genel not ortalaması 85-89 puan aralığında olan öğretmen adaylarının üniversite yaşamına uyumlarının daha olumlu olduğu anlaşılmaktadır $(\overline{\mathrm{x}}=5.32)$. Ölçek alt faktörler kapsamında analiz edildiğinde genel not ortalaması 85-89 puan aralığında olan öğretmen adaylarının Duygusal Uyum $(\overline{\mathrm{x}}=4.77)$, Kişisel Uyum ( $\overline{\mathrm{x}}=6.25)$, Akademik Uyum ( $\overline{\mathrm{x}}=5.35)$ ve Sosyal Uyum ( $\overline{\mathrm{x}}=6.33)$ düzeylerinin daha olumlu olduğu, genel not ortalaması 80-84 puan aralığında olan öğretmen adaylarının Karşı Cinsle İlişkiler $(\overline{\mathrm{x}}=5.28)$ ve Üniversite Ortamına Uyum ( $\bar{x}=4.80)$ düzeylerinin daha olumlu olduğu anlaşılmaktadır.

Üniversite yaşamına uyum düzeyi öğretmen adaylarının geldikleri coğrafi bölgeler dikkate alınarak incelenmeden önce varyansların homojenliği incelenmiştir. Levene testi sonuçları Tablo 8'deki gibidir: 
Tablo 8. Varyansların homojenliği testi

\begin{tabular}{llll}
\hline Levene Statistic & df1 & df2 & Sig. \\
\hline .759 & 7 & 192 & .553 \\
\hline
\end{tabular}

Tablo 8'de görüldüğü gibi p değeri .05'ten büyük olduğu için (.553) varyansların homojen ve varyans analizine uygun olduğu söylenilebilir. Tablo 9'da öğretmen adaylarının üniversite yaşamına uyum düzeylerinin coğrafi bölgeye göre analiz sonuçları yer almaktadır.

Tablo 9. Üniversite yaşamına uyum düzeyinin bölgeye göre varyans analizi sonuçları

\begin{tabular}{|c|c|c|c|c|c|c|}
\hline Faktör & $\begin{array}{l}\text { Varyansın } \\
\text { Kaynağı }\end{array}$ & $\begin{array}{c}\text { Kareler } \\
\text { Toplamı }\end{array}$ & sd & $\begin{array}{r}\text { Kareler } \\
\text { Ortalamasi }\end{array}$ & $\mathbf{F}$ & $\mathbf{p}$ \\
\hline \multirow{3}{*}{$\begin{array}{l}\text { Üniversite Ortamına } \\
\text { Uyum }\end{array}$} & Gruplar aras1 & 9.90 & 7 & 1.41 & \multirow[t]{3}{*}{1.29} & \multirow[t]{3}{*}{.25} \\
\hline & Gruplar içi & 194.39 & 192 & 1.09 & & \\
\hline & Toplam & 204.30 & 199 & & & \\
\hline \multirow[t]{3}{*}{ Duygusal Uyum } & Gruplar aras1 & 10.54 & 7 & 1.50 & \multirow[t]{3}{*}{1.28} & \multirow[t]{3}{*}{.26} \\
\hline & Gruplar içi & 209.18 & 192 & 1.17 & & \\
\hline & Toplam & 219.72 & 199 & & & \\
\hline \multirow[t]{3}{*}{ Kişisel Uyum } & Gruplar aras1 & 13.23 & 7 & 1.89 & \multirow[t]{3}{*}{1.82} & \multirow[t]{3}{*}{.08} \\
\hline & Gruplar içi & 184.13 & 192 & 1.03 & & \\
\hline & Toplam & 197.36 & 199 & & & \\
\hline \multirow[t]{3}{*}{ Karşı Cinsle İlişkiler } & Gruplar aras1 & 10.43 & 7 & 1.49 & \multirow[t]{3}{*}{1.27} & \multirow[t]{3}{*}{.26} \\
\hline & Gruplar içi & 207.52 & 192 & 1.16 & & \\
\hline & Toplam & 217.96 & 199 & & & \\
\hline \multirow[t]{3}{*}{ Akademik Uyum } & Gruplar aras1 & 12.00 & 7 & 1.71 & \multirow[t]{3}{*}{1.59} & \multirow[t]{3}{*}{.13} \\
\hline & Gruplar içi & 191.06 & 192 & 1.07 & & \\
\hline & Toplam & 203.07 & 199 & & & \\
\hline \multirow[t]{3}{*}{ Sosyal Uyum } & Gruplar aras1 & 10.44 & 7 & 1.49 & \multirow[t]{3}{*}{1.30} & \multirow[t]{3}{*}{.24} \\
\hline & Gruplar içi & 202.92 & 192 & 1.14 & & \\
\hline & Toplam & 213.36 & 199 & & & \\
\hline \multirow[t]{3}{*}{ Tüm Ölçek } & Gruplar aras1 & 6.92 & 7 & .98 & \multirow[t]{3}{*}{1.62} & \multirow[t]{3}{*}{.13} \\
\hline & Gruplar içi & 108.05 & 192 & .60 & & \\
\hline & Toplam & 114.97 & 199 & & & \\
\hline
\end{tabular}

Üniversite yaşamına uyum düzeyi öğretmen adaylarının geldikleri coğrafi bölgeler dikkate alınarak incelendiğinde, adayların uyum düzeyleri arasında anlamlı farklılık olmadığı anlaşılmaktadır, $\mathrm{F}(7,192)=1.62, \mathrm{p}<.05$. Ayrıca, alt ölçekler incelendiğinde, benzer şekilde, araştırmaya katılan öğretmen adaylarının uyum düzeyleri arasında anlamlı farklılık görülmemiştir. Bununla birlikte, her ne kadar analizler sonucunda anlamlı farklılık görülmese de, Marmara Bölgesi'nden gelen öğretmen adaylarının en yüksek uyum düzeyine $(\overline{\mathrm{x}}=5.14)$, Doğu Anadolu Bölgesi'nden gelen öğretmen adayların ise en düşük uyum düzeyine $(\bar{x}=4.19)$ sahip olduğu anlaşılmaktadır. 


\subsection{Görüşme Verilerine İlişsin Bulgular}

Görüşmelerden elde edilen veriler kişisel uyum, sosyal uyum ve akademik uyum olmak üzere üç ana kategori altında toplanmıştır. Verilerin analizi sonucunda elde edilen bulgular aşağıdaki gibidir:

Kişisel Uyum

Öğretmen adaylarının üniversite yaşamına kişisel uyumları, beklentiler ve aidiyet olmak üzere iki alt kategoride incelenmiştir.

Öğretmen adaylarının kişisel uyum kapsamında beklentilerle ilgili ifadeleri aşağıdaki gibidir:

- Sosyal aktivitesi fazla olan, akademik kadrosu başarılı olan, sosyalleşme faaliyetleri fazla olan (Öğretmen Adayı 14)

- Daha profesyonel ve aktif bir ortam hayal etmiştim, hocaların eğitim düzeyinin yüksek olduğu ve okul ortamının daha faal olduğu kendimi geliştirebilmem için daha güzel bir ortam olmasını isterdim (Öğretmen Adayı 19)

- Yeni şeyler kazanabileceğim, aileden uzakta bir ortamda yaşamayı öğrenebileceğim, farklı düşünceler ve farklı kişiler tanıyabileceğim şu an ve gelecekte bana mutluluk kazandırabilecek bir ortam hayal ediyordum (Öğretmen Adayı 12)

Öğretmen adayı 14 üniversiteden beklentisini sosyal imkânların fazla olduğu ve akademik kadrosu başarılı olan bir ortam olarak açıklamıştır. Öğretmen Adayı 19 ise kendini akademik olarak geliştirmeyi beklediğini ifade etmiştir. Öğretmen Adayı 12'nin aileden uzak bir ortamda farklı deneyimler yaşamak gibi beklentileri olduğu görülmektedir. Öğretmen adaylarının bu ifadelerinden üniversite yaşamına ilişkin beklentilerinin, sosyal ihtiyaçlarının giderilmesine yönelik olduğu anlaşılmaktadır. Üniversitenin sunacağı akademik firsatların ise pek çok öğretmen adayı için ikinci planda olduğu görülmektedir. Adaylarının beklentileri değerlendirildiğinde pek çoğu için ailesinden ayrı, sosyal olarak daha aktif/eğlenceli ve ders yoğunluğunun daha az olduğu bir ortamda yeni bir hayat kurmayı bekledikleri görülmektedir. Bir yetişkin olarak, kendi yaşamlarının sorumluluğunu aldıkları bu ilk yıllarında daha az görev ve daha çok eğlenmeyi hayal ettikleri anlaşılmaktadır.

Bulgular öğretmen adaylarının bir bölümünün kendini yeterince buraya ait hissetmediğine dikkati çekerken, az sayıda öğretmen adayının üniversite ile bağ kuramadığını göstermektedir. Öğretmen adaylarının aidiyet kapsamındaki ifadeleri aşağıdaki gibidir:

- Kendimi buraya ait hissediyorum, İzmir'den geldiğim için burayı çok içten buldum (Öğretmen Adayı 7)

- Geldiğim şehirden dolayı (İzmir) burası çok farklı gelmedi ve ait olamama gibi bir durumum olmadı (Öğretmen Adayı 6)

- Hayır hissetmiyorum, ortam çok yabanc1 ve samimiyetsiz geliyor...bazen ortamdan soyutlanmış gibi oluyorum, ne işim var burada diyorum (Öğretmen Adayı 13)

- Hayır buraya ait hissetmiyorum, aksine buradan en kısa zamanda gitmek istiyorum (Öğretmen Aday1 19)

Öğretmen adaylarının yukarıdaki ifadeleri incelendiğinde öğrenim görmekte oldukları şehre benzer özellikler gösteren şehirlerden gelenlerin daha hızlı uyum sağladıkları ve aidiyet duygularının geliştiği anlaşılmaktadır. Örneğin Öğretmen Adayı 7 ve Öğretmen Adayı 6 üniversitenin bulunduğu şehri geldikleri şehre benzeterek uyum sorunu yaşamadıklarını ifade etmiştir. Öğretmen Adayı 13 ve Öğretmen Adayı 19'un ifadeleri incelendiğinde ise aidiyet duygusunun gelişmediği ve mutsuz hissettikleri anlaşılmaktadır. Öğretmen Adayı 13'ün kendini yabancı hissettiği görülürken Öğretmen Adayı 19'un da gitmek istediğini ifade ettiği görülmektedir.

Bulgular öğretmen adaylarının üniversite yaşamından beklentileri kapsamında en çok sosyal olarak aktif olmayı ve sosyal çevrelerini genişletmeyi arzuladıklarını göstermektedir. Bununla birlikte, pek çok öğretmen adayının eğitim düzeyi yüksek öğretim elemanlarından dersler alarak daha profesyonel bir ortamda öğrenim görme, sempozyum ve konferans vb. faaliyetlere katılarak akademik 
olarak kendilerini geliştirme ve iyi bir eğitim alma beklentisinde oldukları anlaşılmaktadır. Buna ek olarak bazı öğretmen adaylarının ise aileden uzakta, yeni deneyimler kazanma, sorumluluk alma ve hayatı öğrenmeye ilişkin beklentilerinin olduğu görülmektedir. Ayrıca az sayıda öğretmen adayının da daha az sayıda ders alma, devam zorunluluğunun olmaması ve sınava girmeme gibi beklentilerinin olduğu anlaşılmaktadır. Çok daha az sayıda öğrencinin ise üniversiteye ilişkin herhangi bir beklentisinin olmadığını ifade ettikleri görülmektedir.

\section{Sosyal Uyum}

Öğretmen adaylarının üniversitede sosyal yaşama ilişkin görüşlerinin genel itibarı ile olumlu olduğu anlaşılmaktadır. Bu doğrultuda, öğretmen adaylarının sosyal ortama ilişkin ifadeleri aşağıdaki gibidir:

- Şehir ve üniversitenin bize sunduğu sosyal imkanlar yeterli düzeyde (Öğretmen Adayı 11)

- Sosyal ortam gayet güzel (Öğretmen Adayı 18)

-Farklı arkadaşlık ilişkileri sonucundan doğan farklı ve eğlenceli ortamlar var (Öğretmen Adayı 12)

\section{- Çok çeşitli sosyal ortamlar olduğunu düşünüyorum (Öğretmen Adayı 2)}

Öğretmen adaylarının ifadelerinden üniversite yaşamının sunduğu sosyal yaşamı eğlenceli buldukları anlaşılmaktadır. Örneğin; Öğretmen Adayı 11 şehrin olanakları ve üniversitenin sosyal faaliyetlerinin yeterli düzeyde olduğu ifade etmiştir. Buna ek olarak, Öğretmen Adayı 18'in sosyal ortamı mükemmel ve güzel olarak tanımladığı görülmektedir. Öğretmen Adayı 12 ise farklı arkadaş ilişkilerinin sosyal ortamı eğlenceli hale getirdiğini ifade etmiştir. Öğretmen Adayı 2 de sosyal ortamın çeşitliliğine dikkati çekmiştir. Öğretmen adaylarının yukarıdaki ifadeleri değerlendirildiğinde pek çoğunun içinde bulunduğu sosyal ortama uyumlu ve ortamdan memnun oldukları düşünülmektedir.

Ayrıca, öğretmen adaylarının büyük bölümü genel olarak öğrenci toplulukları hakkında bilgiye sahip olmadığını ifade etmiştir. Bununla birlikte, öğretmen adaylarının bir kısmı kültürel faaliyetleri yeterli bulurken, bir diğer bölümünün de yetersiz olduğunu düşündüğü görülmektedir. Öğretmen adaylarının bu kapsamdaki görüşleri aşă̆ıdaki gibidir:

- Herhangi bir öğrenci topluluğunun faaliyetine denk gelmedim (Öğretmen Aday1

- Öğrenci toplulukları pek fazla aktif değil ya da biz farkında olamıyoruz daha aktif olunabilirdi bence (Öğretmen Aday1 8)

- Kültürel faaliyetler daha fazla arttırılmalı (Öğretmen Adayı 5)

- Kültürel faaliyetler çok fazla düzenlenmiyor (Öğretmen Adayı 21)

Öğretmen adaylarının öğrenci topluluklarına ilişkin ifadeleri incelendiğinde öğrenci toplulukları hakkında yeterince bilgi sahibi olmadıkları ve katılım göstermedikleri anlaşılmaktadır. Örneğin Öğretmen Adayı 19 öğrenci topluluklarının herhangi bir faaliyetine rastlamadığını ifade ederken Öğretmen Adayı 8 ise öğrenci topluluklarının yeterince aktif olmadıklarını belirtmiştir. Öğretmen adaylarının bu ifadelerinden sosyal uyum kapsamında öğrenci topluluklarının faaliyetlerinden yeterince yararlanamadıkları anlaşılmaktadır. Sosyal uyumun bir diğer unsuru kültürel faaliyetlerdir. Öğretmen adayları sosyal uyum kapsamında kültürel faaliyetlerin yeterli olmadığ görüşündedir. Örneğin; Öğretmen Aday1 5 ve Öğretmen Adayı 21 kültürel faaliyetlerin çok fazla düzenlenmediğini daha fazla etkinlik yapılması gerektiğini vurgulamıştır. Öğretmen adaylarının hem ögrenci toplulukları hem de kültürel faaliyetler açısından sosyal uyumları değerlendirildiğinde yeterince aktif olmadıkları düşünülmektedir.

Bulgular, öğretmen adaylarının çoğunun arkadaşlık ilişkilerini samimiyetsiz ve çıkarcı bulduğunu ortaya koymaktadır. Bununla birlikte, her ne kadar arkadaş ilişkilerine olan bakış açıları olumsuz olsa da pek çok öğretmen adayı üniversite yaşamındaki sosyal ortamı "hızlı", "çeşitli ve "eğlenceli” kavramlarıyla açıklamışlardır. Ayrıca, öğretmen adaylarının büyük bölümünün öğrenci 
topluluklarının faaliyetlerini ve kültürel etkinlikleri yetersiz olarak nitelendirdiği anlaşılmaktadır. $\mathrm{Bu}$ doğrultuda, öğretmen adaylarının üniversite yaşamındaki sosyal uyum kapsamında arkadaşlık ilişkileri ile ilgili ifadeleri aşă̆ıdaki gibidir:

- Samimiyetten uzak bir ortam var, insanlar bireysel hareket etmeyi tercih ediyor (Öğretmen Aday1 19)

- Arkadaşlık ilişkileri bakımından pek samimi bulmuyorum (Öğretmen Adayı 21)

- İnsanlara güvenmekte zorluk çekiyorum, çıkar ilişkisine dayalı bir ilişki var (Öğretmen Aday1 13)

- Genelde çıkar ilişkisine dayalı olduğunu düşünüyorum (Öğretmen Adayı 7)

Öğretmen adaylarının yukarıdaki ifadeleri dikkate alındığında özellikle çıkar ilişkilerini vurguladıkları görülmektedir. Bununla birlikte, öğretmen adaylarının ifade ettikleri bir diğer husus arkadaş ilişkilerini samimiyetsiz bulmalarıdır. Örneğin; Öğretmen Adayı 19 ve 21 arkadaş ilişkilerini samimiyetsiz bulduklarını belirtmiştir. Öğretmen Adayı 7 ve 13 ise arkadaşlık ilişkilerini çıkarcı bulduklarını ifade etmiştir. Öğretmen adaylarının bu ifadelerinden üniversite ortamındaki arkadaşlık ilişkilerine yeterince güvenmedikleri ve kendilerini bu konuda mutlu hissetmedikleri anlaşılmaktadır. Kişilerin kendi çıarları doğrultusunda hareket etmeleri sonucunda samimi ve içten arkadaşlık ilişkileri kurmaktan yoksun kaldıkları düşünülmektedir.

\section{Akademik Uyum}

$\mathrm{Bu}$ araştırma kapsamında son olarak öğretmen adaylarının akademik beklentilerinin karşılanıp karşılanmadığı araştırılmıştır. Bu kapsamda, öğretim elemanları ile iletişim, eğitim düzeyi, derslerin işlenişi ve sınavlar konusundaki beklentilerinin neler olduğu belirlenmiştir. Öğretmen adaylarının çok büyük bölümünün öğretim elemanları ile olan iletişimlerini olumlu olarak değerlendirdiği anlaşılmaktadır. Bununla birlikte öğretmen adayların çoğu eğitim seviyesini yüksek ve yeterli olarak tanımlamıştır. Öte yandan öğretmen adaylarının neredeyse tümü derslerin işlenişini klasik, ezbere dayalı ve lise öğrenimine benzer düzeyde bulduklarını ifade etmiştir. Benzer şekilde, sınavları da lise düzeyindeki sınavlara benzettiklerini ve sınavları gereksiz bulduklarını ifade ettikleri anlaşılmaktadır. Öğretmen adaylarının akademik uyum kapsamındaki ifadeleri aşağıdaki gibidir:

- Okulumuzun öğretim elemanlarına istediğimiz her an e-posta ve telefon yoluyla ulaşabiliyor ve dönüt alabiliyoruz, öğrenci öğretmen iletişim ilgili ve etkili (Öğretmen Adayı 11)

- Okuduğum bölüm için buranın en iyi üniversite olduğunu söylemişlerdi ve haklılarmış, akademik kadrosu ve eğitimi gerçekten güzel (Öğretmen Adayı 17)

-Derslerin işlenişi birkaç ders hariç liseden farksız, ezbere dayalı sistem mevcut (Öğretmen Aday1 7)

- Sinavlar ortaokul ve liseden farksız, daha yaratıcı ve düşündürücü sorular sorulmasını beklerdim (Öğretmen Adayı 19)

Öğretmen adaylarının öğretim elemanları ile iletişimlerini değerlendirdikleri ifadeler incelendiğinde bu konudaki görüşlerinin olumlu olduğu anlaşılmaktadır. Örneğin, Öğretmen Adayı 11 öğretim elemanlarının e-posta ve telefon yoluyla onlarla iletişim kurduklarını bu nedenle iletişimlerinin iyi olduğunu ifade etmiştir. Öğretmen adaylarının bu ifadelerinden akademik uyum kapsamında öğretim elemanları ile iletişimlerinin iyi olduğu anlaşılmaktadır. Bununla birlikte öğretmen adaylarının üniversite yaşamını eğitim bakımından değerlendirdiklerinde öğrenim gördükleri üniversitenin eğitim düzeyini yüksek buldukları görülmektedir. Örneğin, Öğretmen Adayı 17 öğretmen eğitimi ve akademik kadro açısından en iyi üniversitede olduğunu ifade etmiştir. Öğretmen adaylarının bu ifadelerinden aldıkları eğitim düzeyinden memnun oldukları anlaşılmaktadır. Ancak öte yandan öğretmen adaylarının derslerin işlenişine ilişkin görüşleri incelendiğinde her ne kadar eğitim düzeyinden memnun olsalar da dersleri liseden farksız, klasik ve ezberci buldukları görülmektedir. Örneğin, Öğretmen Adayı 7 derslerin ezbere dayalı işlendiğini ve liseden farklı olmadığını ifade etmiştir. Bu doğrultuda, öğretmen adaylarının derslerin işleniş biçiminden yeterince memnun olmadıkları düşünülmektedir. Öğretmen adaylarının sınavlara ilişkin ifadeleri incelendiğinde sınavları yeterli bulmadıkları anlaşılmaktadır. 
Örneğin, Öğretmen Adayı 19 sınavların daha yaratıcı olması gerektiğini ifade etmiştir. Bu ifadelerden, öğretmen adaylarının sınavlar konusundaki beklentilerinin gerçekleşmediği sonucuna varılmıştır.

\section{TARTIŞMA ve SONUÇ}

Öğretmen adaylarının öğrenim yaşantılarının ilk yılında üniversite yaşamına uyumunu konu alan bu çalışmada adayların üniversite yaşamına uyum düzeylerinin çok yüksek olmadığ görülmektedir. Alan yazın incelendiğinde elde edilen bu bulgunun çeşitli çalışmalar ile benzerlik gösterdiği anlaşılmaktadır (Aktaş, 1997; Erdoğan vd. 2005; İkiz \& Mete-Otlu, 2015; Mercan \& Yıldız, 2011; Özkan \& Yılmaz, 2010). Örneğin Erdoğan vd. (2005) öğretmen adaylarının üniversite ortamını beklentilerinin altında buldukları ve memnun olmadıkları sonucuna ulaşmıştır. Benzer şekilde, İkiz ve Mete-Otlu'nun (2015) çalışmasında üniversite öğrencilerinin kendisini yalnız hissettiği ve grup içi uyum sorunları yaşadığı anlaşılmaktadır. Bulgular incelendiğinde, en yüksek ortalamanın Sosyal Uyum alt faktörüne ait olduğu görülmektedir. Bu bulguyu destekler nitelikte, adaylar görüşmeler kapsamında her ne kadar arkadaşlık ilişkilerini samimi bulmadıklarını belirtmiş olsalar da büyük bölümünün sosyal anlamda aktif olma beklentisi içinde olduğu anlaşılmaktadır. Özellikle, şehrin üniversite öğrencileri açısından sunduğu imkânlardan memnun olduklarını ifade ettikleri görülmektedir. Sosyal uyumun bir parçası olarak Üniversite Ortamına Uyum faktörü incelendiğinde, her ne kadar adayların ifadelerinden sosyalleşme beklentilerinin yüksek olduğu görülse de üniversitenin fiziki yapısına ilişkin beklentilerinin gerçekleşmediği anlaşılmaktadır. Öğretmen adaylarının en yüksek ortalamaya sahip oldukları ikinci alt faktör Kişisel Uyum'dur. Görüşmelerden elde edilen verilerin analizinde, Duygusal Uyum ve Karşı Cinsle İlişkiler alt faktörleri de Kişisel Uyum kapsamında ele alınmıştır. Görüşmeler sırasında kişisel uyuma ilişkin elde edilen bulgular öğretmen adaylarının büyük bölümünün aidiyet duygusunun gelişmiş olduğunu ifade ettiklerini göstermektedir. Aidiyet duygusunun gelişmesi kişisel uyum açısından önemli olmakla birlikte, adaylar arkadaşlık ilişkilerini samimi bulmadıkları ve insanlara güvenmekte zorluk çektiklerini ifade etmektedir. Bu bilgilerden hareketle, adaylar her ne kadar kendisini bu üniversitenin parçası olarak görse de hem duygusal hem de sosyal arkadaşlık ilişkilerine temkinli yaklaştıkları görülmektedir. Bu durum alanyazındaki kişisel uyumu konu alan benzer çalışmaların sonuçları ile paralellik göstermektedir. Örneğin, Sivrikaya (1992) öğretmen adaylarının uyum düzeylerini belirlemeye yönelik çalışmasında, öğretmen adaylarının kişisel uyum düzeylerinin çok yüksek olmadığını ortaya koymuştur. Benzer şekilde, Öztemel'in (2010) teknik eğitim fakültesinde öğrenim gören öğretmen adaylarının uyum düzeylerini belirlemek amacıyla yapmış olduğu çalışmasında öğretmen adaylarının kişisel uyum kapsamındaki görüşlerinin bu çalışmanın sonuçları ile benzerlik gösterdiği anlaşılmaktadır. Akademik Uyum faktörü dikkate alındığında, adayların eğitimin niteliğini yüksek bulmakla birlikte derslerin işlenişi ve sınavlara ilişkin görüşlerinin olumsuz olduğu anlaşılmaktadır. Elde edilen bu bulgunun alanyazın tarafından desteklendiği anlaşılmaktadır. Örneğin, Erkan ve diğerleri (2011) çalışmalarında sekiz farklı üniversitede öğrenim gören öğrencilerin akademik uyum sorunu ile karşı karşıya kaldığını ortaya koymuştur. Benzer şekilde Aladağ, Bayrak ve Bülbül (2013) ile Bülbül ve Acar-Güvendir'in (2014) çalışmalarında öğrencilerin akademik görevleri yerine getirme ile ilgili sorunlar yaşadığı bilinmektedir. Bu açıklamalar ışığında, adayların hem Üniversite Yaşamı Ölçeği'nden almış oldukları puanlar hem de görüşmeler kapsamındaki ifadeleri birlikte değerlendirildiğinde verilerin kendi içinde tutarlı olduğu anlaşılmaktadır.

Öğretmen adaylarının üniversite yaşamına uyumları cinsiyete göre incelendiğinde, ölçeğin tümü ve alt faktörler kapsamında cinsiyete göre anlamlı farklılık bulunmamaktadır. Bununla birlikte, Akademik Uyum kapsamında kadın öğretmen adaylarının ortalama puanlarının erkek öğretmen adaylarına göre yüksek olduğu görülmektedir. Bu bulgu, benzer çalışmaların sonuçları ile örtüşmektedir (Bulut \& Bulut-Serin, 2016). Kadın öğretmen adaylarının Akademik Uyum kapsamında erkek öğretmen adaylarından daha olumlu görüşe sahip olmaları mesleğe ilişkin tutumları ile açıklanabilir. Örneğin, alanyazın kadın öğretmen adaylarının öğretmenlik mesleğine ilişkin tutumlarının erkek öğretmen adaylarına göre daha olumlu olduğunu vurgulamaktadır (Bozdoğan, Aydın \& Yıldırım, 2007; Çapri \& Çelikkaleli, 2008; Terzi \& Tezci, 2007). Buna ek olarak, öğretmenlik mesleğine ilişkin metaforik çalışmalar adayların öğretmenliği çoğunlukla annelik olgusuna benzettiklerini göstermektedir (Budak \& Kula, 2017; Çocuk, Yokuş \& Tanrıseven, 2015; Koç, 2014). Bu çalışmaları destekler şekilde, öğretmenlik mesleğini tercih etmede cinsiyetin önemli bir etken olduğu ve kadın öğretmen adaylarının mesleğe daha bilinçli olarak geldikleri bilinmektedir (Çermik, Doğan \& Şahin, 2010; Özsoy, Özsoy, Özkara \& Memiş, 2010). Ekici'ye (2008) göre olumlu tutum iletişimi dolayısıyla da öğrenme-öğretme sürecinin niteliğini arttırmaktadır. Ayrıca, öğretmen adaylarının mesleğe ilişkin 
olumlu tutumları meslek bilgisi derslerine ilişkin tutumlarının da olumlu olmasına katkı sağlamaktadır (Ekici, 2008). Bu doğrultuda, kadın öğretmen adaylarının akademik uyumlarının erkek öğretmen adaylarına göre daha olumlu olmasının cinsiyete özgü roller sebebiyle mesleğe ilişkin tutumlarının daha olumlu olmasından kaynaklandığı şeklinde yorumlanabilir.

Bulgular, öğretmen adaylarının öğrenim görmekte oldukları anabilim dalına göre incelendiğinde, Sınıf Eğitimi ve Okul Öncesi Eğitimi anabilim dalında öğrenim gören öğretmen adaylarının üniversite yaşamına uyum düzeyleri arasında anlamlı farklılık görülmemektedir. Elde edilen bu bulgu alanyazındaki benzer çalışmaların sonuçları ile paralellik göstermektedir (Bülbül \& Acar-Güvendir, 2014). Öğretmen adaylarının öğrenim görmekte oldukları bölümü tercih etme sebepleri ve üniversite yaşamından beklentilerini konu alan çalışmaların bulguları incelendiğinde Temel Eğitim alanında öğrenim görmekte olan öğretmen adaylarının tercih sebepleri ve beklentilerinin benzer olduğu görülmektedir (Akbayır, 2002; Çermik, Doğan, \& Şahin, 2010; Özsoy vd. 2010). Buna ek olarak, Sınıf Eğitimi ve Okul Öncesi Eğitimi anabilim dalında öğrenim gören öğretmen adaylarının, meslek bilgisi derslerinin yanı sıra alan eğitimi derslerinin katkısıyla diğer anabilim dallarına göre mesleğe yönelik tutumlarının daha olumlu olduğu bilinmektedir (Şahin-Taşkın \& Hacıömeroğlu, 2010). Alanyazından elde edilen bu bilgiler ışığında, tercihe ilişkin sebepler ile öğretmenlik mesleğine ilişkin tutum ve beklentiler benzer olduğu için grupların üniversite yaşamına uyum düzeylerinin de birbirine benzer olduğu düşünülmektedir.

Öğretmen adaylarının üniversite yaşamına uyum düzeyleri akademik başarıları dikkate alınarak incelendiğinde istatistiksel olarak anlamlı farklılık bulunduğu görülmektedir. Genel not ortalaması 8589 arasında olan öğretmen adaylarının uyum düzeylerinin daha olumlu olduğu anlaşılmaktadır. Alanyazından elde edilen bulguların bu bulguyu desteklediği görülmektedir (Duru \& Balkıs, 2015). Alanyazın öğretmen adaylarının üniversiteye giriş nedenlerinin üniversite yaşamına uyumun yanı sıra akademik başarı üzerinde de etkili olduğunu göstermektedir (Batman \& Yiğit, 2016). Buna ek olarak, öğretmenlik mesleğine istekli olarak gelen öğrencilerin daha başarılı olacağı düşünülmektedir. Ayrıca, öğretmen adaylarının Akademik Uyum alt faktöründen almış oldukları puanların ortalamasının genel uyumun ortalamasından yüksek olduğu görülmektedir. Bu durum, öğretmen adaylarının akademik uyum sorunlarının uyumun diğer alanlarına göre daha olumlu olduğuna işaret etmektedir. $\mathrm{Bu}$ bilgilerden hareketle, ögretmen adaylarının akademik olarak zorlanmadıkları için üniversite yaşamına uyumlarının da daha olumlu olduğu düşünülmektedir.

$\mathrm{Bu}$ çalışma kapsamında ele alınan bir diğer değişken öğretmen adaylarının gelmiş oldukları coğrafi bölgelerdir. Öğretmen adaylarının üniversite yaşamına uyum düzeyleri ile geldikleri coğrafi bölge arasında istatistiksel olarak anlamlı farkl1lık bulunmamaktadır. Bu bulgu alanyazındaki çalışmaların sonuçları ile benzerlik göstermektedir (Mercan \& Yıldız, 2011). Çalışmanın grubunun özellikleri incelendiğinde yedi coğrafi bölgeden gelen öğretmen adaylarının çalışmaya katıldıkları görülmektedir. Her ne kadar ölçekten elde edilen verilerin analizinde anlamlı farklılık görülmese de; görüşmelerden elde edilen bulgular, İzmir'den gelen öğretmen adaylarının öğrenim gördükleri şehri geldikleri yere çok benzettikleri, bu nedenle de uyum sorunu yaşamadıklarını ifade ettikleri görülmektedir. Ayrıca, Diyarbakır ve Ağrı gibi daha uzak coğrafi bölgelerden gelen adayların ise bağ kurmakta zorlandıklarını ifade ettikleri görülmektedir. Nicel verilerden elde edilen bulgular yakından incelendiğinde her ne kadar istatistiksel olarak anlamlı farkl1lı bulunmasa da nitel bulguları destekleyen bir şekilde, İzmir İstanbul gibi bu çalışmanın yapıldığı şehre yakın bölgelerden gelen öğrencilerinin uyum düzeylerinin daha olumlu olduğu anlaşılmaktadır.

Öğretmen adaylarının üniversite yaşamına uyumunu kişisel, sosyal ve akademik açıdan ele alan bu çalışma öğretmen eğitiminin niteliğinin arttırılmasına yönelik önemli bilgiler sunmaktadır. Bununla beraber, bu araştırmanın bulguları Temel Eğitim Bölümü’nde öğrenim gören öğretmen adayları ve bu öğretmen adaylarının görüş̧leri ile sınırlıdır. Bu nedenle, çalışma sonuçlarının genellenilebilirliğinin arttırılması amacıyla farklı üniversitelerin Temel eğitim bölümlerinde öğrenim gören öğretmen adayları ile çalışmalar yapılması önerilmektedir. Ayrıca, her ne kadar nicel bulgular kapsamında coğrafi bölge değişkenine göre anlamlı farklılık bulunmasa da görüşmeler sırasında öğretmen adaylarının gelmiş oldukları şehrin etkisiyle uyum sürecini daha kolay atlattıkları ya da daha çok zorlandıklarını ifade ettikleri görülmektedir. Bu nedenle, uyum süreci ve bulunulan coğrafya ilişkisi hakkında kapsamlı bilgi edinebilmek amacıyla öğrenim gördüğü üniversiteye farklı coğrafi bölgelerden gelen öğrencilerin katılımı ile çalışmalar yapılmasının bu konuya ilişkin ayrıntılı bilgiler sağlayacağı düşünülmektedir. 
Öğretmen Adaylarının Üniversite Yaşamına Sosyal, Kişisel ve Akademik Uyumları 


\section{KAYNAKLAR}

Akbayır, K. (2002). Öğretmenlik mesleğine yönelmede ailenin ve branş seçiminde cinsiyetin rolü. $V$. Ulusal Fen Bilimleri ve Matematik Eğitimi Kongresi Dergisi, 2, 1183-1188.

Aladağ, M., Kağnıcı, Y., Tuna, E., \& Tezer, E. (2003). Üniversite yaşamı ölçeği: ölçek geliştirme ve yapı geçerliği üzerine bir çalışma. Türk Psikolojik Danışma ve Rehberlik Dergisi, 2(20), 41-47.

Aladağ, M. Bayrak, Ö. \& Bülbül, T. (2013). Meslek yüksekokulu öğrencilerinin yükseköğretim yaşamına uyum düzeylerinin çeşitli değişkenlere göre incelenmesi. Sakarya Üniversitesi Eğitim Dergisi. 3(2), 6-20.

Alpan, A. (1992). Cumhuriyet Üniversitesi ve Erciyes Üniversitesi Fen ve Edebiyat Fakültesi Öğrencilerinde Çevreye ve Üniversiteye Uyum Sorunları, Sivas Cumhuriyet Üniversitesi Sosyal Bilimler Enstitüsü (Yayınlanmamış Yüksek Lisans Tezi).

Batman, D., \& Yiğit, N. (2016). Öğretmen adaylarının akademik başarılarını etkileyen faktörleri belirleme ölçeği geliştirilmesi. Kastamonu Education Journal, 24(1), 217-232.

Bilal, G. (1984). Demokratik ve Otoriter Olarak Algılanan Ana-Baba Tutumlarının Çocukların Uyum Düzeylerine Etkisi, Hacettepe Üniversitesi Sosyal Bilimler Enstitüsü (Yayınlanmamış Doktora Tezi).

Bozdoğan, A. E., Aydın, D., \& Yıldırım, K. (2007). Öğretmen adaylarının öğretmenlik mesleğine ilişsin tutumları. Ahi Evran Üniversitesi Kırşehir Eğitim Fakültesi Dergisi, 8(2), 83-97.

Budak, Y., \& Kula, S. S. (2017). Sınıf öğretmeni adaylarının öğretmenlik mesleğine ilişkin algilar1. Journal of Kirsehir Education Faculty, 18(2), 311-329.

Bulut, C., \& Serin, N. B. (2016). Öğretmen adaylarının üniversite yaşamına uyum düzeyleri ile yaşam doyumu arasındaki ilişkinin incelenmesi. International Journal of New Trends in Arts, Sports \& Science Education, 5(4), 1-7.

Bülbül, T., \& Acar-Güvendir, M. (2014). Üniversite birinci sınıf öğrencilerinin yükseköğretim yaşamına uyum düzeylerinin incelenmesi. Eğitim Bilimleri Araştırmaları Dergisi, 4(1), 397418.

Büyüköztürk Ş., Kılıç-Çakmak, E., Akgün, Ö. E., Karadeniz, Ş., \& Demirel, F. (2012). Bilimsel araştırma yöntemleri (Geliştirilmiş 13. Baskı). Ankara: Pegem Akademi.

Charlton, J. P., Barrow, C., \& Hornby-Atkinson, P. (2006). Attempting to predict withdrawal from higher education using demographic, psychological and educational measures. Research in PostCompulsory Education, 11, 31-47.

Creswell, J. W., \& Clark, V. L. P. (2007). Designing and conducting mixed methods research. SAGE Publications, Inc.

Çakar, U., \& Arbak, Y. (2004). Modern Yaklaşımlar Işı̆̆ında Değişen Duygu-Zeka İlişkisi ve Duygusal Zeka. Dokuz Eylül Üniversitesi Sosyal Bilimler Enstitüsü Dergisi, 6(3), 23-48.

Çalık, C. (2006). Örgütsel sosyalleşme sürecinde eğitimin değişen rolü ve önemi. Kastamonu Eğitim Dergisi, 14(1), 1-10.

Çapri, B., \& Çelikaleli, Ö. (2008). Öğretmen adaylarının öğretmenliğe ilişkin tutum ve mesleki yeterlik inançlarının cinsiyet, program ve fakültelerine göre incelenmesi. İnönü Üniversitesi Ĕ̆itim Fakültesi Dergisi, 9(15), 33-53.

Çermik, H., \& Şahin, B. D. A. (2010). Sınıf öğretmenliği öğretmen adaylarının öğretmenlik mesleğini tercih sebepleri. Pamukkale Üniversitesi Eğitim Fakültesi Dergisi, 28(28), 201-212.

Çocuk, H. E., Yokuş, G., \& Tanrıseven, I. (2015). Pedagojik formasyon öğrencilerinin öğretmenliğe ilişkin öz-yeterlik ve metaforik algıları: mersin üniversitesi örneği/pedagogical formation students' self-efficacy and metaforic perceptions related to teaching profession. Mustafa Kemal Üniversitesi Sosyal Bilimler Enstitüsü Dergisi, 12(32), 373-387. 
Duru, E., \& Balkıs, M. (2015). Birey-çevre uyumu, aidiyet duygusu, akademik doyum ve akademik başarı arasındaki ilişkilerin analizi. Ege Eğitim Dergisi, 16(1), 122-141.

Ekici, G. (2008). Öğretmen adaylarının öğretmenlik meslek bilgisi derslerine yönelik tutumları ile öğrenme biçimlerinin değerlendirilmesi. Yüzüncü Yll Üniversitesi Eğitim Fakültesi Dergisi, 5(1), 111-132.

Erdoğan, S., Şanlı, H. S., \& Bekir, H. Ş. (2005). Gazi üniversitesi, eğitim fakültesi öğrencilerinin üniversite yaşamına uyum durumları. Kastamonu Eğitim Dergisi, 13(2), 479-496.

Erkan, S., Cihangir Çankaya, Z., Terzi, Ş., Özbay, Y. (2011). Üniversite psikolojik danışma ve rehberlik merkezlerinin incelenmesi. Mehmet Akif Ersoy Üniversitesi Ë̆itim Fakültesi Dergisi, 22, 174 198.

İkiz, F. E., \& Mete-Otlu, B. (2015). Üniversite yaşamına uyum sürecinde yaşanan sorunlar ve başa çıkma yolları. Celal Bayar Üniversitesi Sosyal Bilimler Dergisi, 13(4), 35-52.

Kaba, İ., \& Keklik, İ. (2016). Öğrencilerin üniversiteye uyumlarında psikolojik dayanıklılık ve psikolojik belirtiler. The Journal of Educational Research, 2(2), 98-113.

Karahan, F., Sardoğan, M. E., Özkamalı, E. ve Dicle, A. N. (2005). Üniversite 1. sınıf öğrencilerinin üniversiteye uyum düzeylerinin sosyokültürel etkinlikler açısından incelenmesi. Çukurova Üniversitesi Eğitim Fakültesi Dergisi, 2 (30), 63- 71.

Kiziltan, G. (1984). Üniversite Öğrencilerinin Kişisel ve Sosyal Uyum Düzeylerini Etkileyen Etmenler, Hacettepe Üniversitesi Sosyal Bilimler Enstitüsü (Yayınlanmamış Doktora Tezi).

Koç, E. S. (2014). Sınıf öğretmeni adaylarının öğretmen ve öğretmenlik mesleği kavramlarına ilişkin metaforik algıları. İönü Üniversitesi Eğitim Fakültesi Dergisi, 15(1), 47-72.

Korkut-- Owen, F. Kepir, D. D., Özdemir, S., Ulaş, Ö. \& Yılmaz, O. (2012). Üniversite öğrencilerinin bölüm seçme nedenleri. Mersin Üniversitesi Eğitim Fakültesi Dergisi, 8(3), 135-151.

Köknel, Ö. (1993). İnsanı anlamak (4. Baskı), İstanbul: Altın Kitaplar.

Mercan, Ç. S., \& Yıldız, S. A. (2011). Eğitim fakültesi birinci sınıf öğrencilerinin üniversiteye uyum düzeylerinin farklı değişkenler açısından incelenmesi. Hasan Ali Yücel Eğitim Fakültesi Dergisi, 8(2), 135-154.

Milli Eğitim Müdürlüğü (2017). Öğretmenlik mesleği genel yeterlikleri. Retrived from https://oygm.meb.gov.tr/meb_iys_dosyalar/2017_12/11115355_YYRETMENLYK_MESLE YY_GENEL_YETERLYKLERY.pdf.

Özdel, L., Bostanc1, M., Özdel, O. ve Oğuzhanoğlu N. K. (2002). Üniversite öğrencilerinde depresif belirtiler ve sosyo-demografik özelliklerle ilişkisi. Anadolu Psikiyatri Dergisi, 3, 155-161.

Özgüven E. (1992). H.Ü. üniversite öğrencilerinin sorunları ve baş etme yolları. Eğitim Fakültesi Dergisi, 7, 5-13.

Özkan, S., \& Yılmaz, E. (2010). Üniversite öğrencilerinin üniversite yaşamına uyum durumları (Bandırma Örneği). Fırat Sağllk Hizmetleri Dergisi, 5(13), 153-171.

Özsoy, G., Özsoy, S., Özkara, Y., \& Memiş, A. D. (2010). Öğretmen adaylarının öğretmenlik mesleğini tercih etmelerinde etkili olan faktörler. İlköğretim Online, 9(3), 201-212.

Öztemel, K. (2010). Teknik eğitim fakültesi öğrencilerinin uyum düzeylerinin incelenmesi. Politeknik Dergisi, 13(4), 319-325.

Sarıkaya, T., \& Khorshid, L. (2009). Üniversite öğrencilerinin meslek seçimini etkileyen etmenlerin incelenmesi: üniversite öğrencilerinin meslek seçimi. Türk Eğitim Bilimleri Dergisi, 7(2), 393423.

Sertel, E., Yıldırım, H., \& Özmen-Akyol, S. (2017). Meslek yüksekokulu öğrencilerinin okul tercih sebepleri ve uyum durumlar1: Sivrihisar örneği. Mehmet Akif Ersoy Üniversitesi Sosyal Bilimler Enstitüsü Dergisi, 9(21), 101-117. 
Sevinc, S., \& Gizir, C. A. (2014). Factors negatively affecting university adjustment from the views of first-year university students: the case of mersin university. Educational Sciences: theory and practice, 14(4), 1301-1308.

Sürücü, M., \& Bacanlı, F. (2010). Üniversiteye uyumun psikolojik dayanıklılık ve demografik değişkenlere göre incelenmesi. Gazi University Journal of Gazi Educational Faculty, 30(2), 375-396.

Şahin, İ., Fırat, N. Ş., \& Zoraoğlu, Y. R. (2010). Üniversite öğrencilerinin düşleri. Ege Eğitim Dergisi, 11(1), 20-38.

Şendil, G., \& Korkut, Y. (2008). Evli çiftlerdeki çift uyumu ve evlilik çatişmasinin demografik özellikler açisindan incelenmesi. Psikoloji Çalışmaları/Studies in Psychology, 28, 15-34.

Sivrikaya, K. (1992). Fatih eğitim fakültesi beden eğitimi ve spor bölümü ögrencilerinin uyum düzeylerinin belirlenmesi ve uyum düzeyleri arasındaki farklılıkların araştırılması (Yayınlanmamış Yüksek Lisans Tezi). Trabzon: Karadeniz Teknik Üniversitesi Sosyal Bilimler Enstitüsü.

Taşkın, Ç. Ş., \& Hacı̈̈meroğlu, G. (2010). İlköğretim bölümü öğretmen adaylarının mesleğe yönelik tutumları: nicel ve nitel verilere dayalı bir inceleme. Illköğretim Online, 9(3), 922-933.

Terzi, A. R., \& Tezci, E. (2007). Necatibey Eğitim Fakültesi öğrencilerinin öğretmenlik mesleğine ilişkin tutumları. Kuram ve Uygulamada Ĕ̈itim Yönetimi, 52(52), 593-614.

Tüzer, V., Tuncel, A., Göka, S., Bulut, S. D., Yüksel, F. V., Atan, A., \& Göka, E. (2010). Marital adjustment and emotional symptoms in infertile couples: gender differences. Turkish Journal of Medical Sciences, 40(2), 229-237. 